\title{
Laboring the Earth: Transnational Reflections on the Environmental History of Work
}

\begin{abstract}
This article explores the intersection of work and nature in environmental history, and it reflects on possible new paths of investigation. More specifically, it focuses on physical labor performed in agriculture and industry-especially in the last two centuries-questioning how experiences in farming, mining, and manufacturing historically have shaped the relationship between working-class people and their environments. Based on secondary literature in English, Italian, and Portuguese, and on original research, the article proposes a tentative interpretative framework for the environmental history of work that incorporates analysis of the landscape as evidence of past human labor, the workplace and its relationship with the local community, and working-class and labor environmental activism. Ultimately, the article highlights the need to investigate the labor/environment dichotomy as a cultural and political construct and seeks to contribute to the formulation of labor-friendly sustainability policies.
\end{abstract}

\footnotetext{
(C) The Author 2013. Published by Oxford University Press on behalf of the American Society for Environmental History and the Forest History Society. All rights reserved. For permissions, please e-mail: journals.permissions@oup.com

Stefania Barca, "Laboring the Earth: Transnational Reflections on the Environmental History of Work," Environmental History 19 (January 2014): 3-27.

doi:10.1093/envhis/emt099

Advance Access publication on October 27, 2013
} 


\section{INTRODUCTION}

In July 2012, an Italian court ordered the forced closure of the Ilva steel plant in Taranto, the largest and one of the oldest such factories in Europe, finding it guilty of serious violations of environmental regulation and of causing what the court recognized as an environmental and public health disaster. Immediately, the case spurred wide attention from the national media, reporting on a long series of citizens' protests against the decision. ${ }^{1}$ There is no such thing as a safe environment/economy relationship_-Taranto's protesters seemed to argue-Working-class people know better, as occupational and environmental risk have been part and parcel with their own history for centuries. They have made a living out of daily negotiations with all sorts of hazards and with death itself. The idea of sustainability is a typically bourgeois pretension, an illusion invented to obscure the reality of economic development in the industrial era. So, why and in the name of what-they seemed to ask-should our entire mode of life and work be destroyed? What will replace it? How can this new reality be worth our sacrifice?

And yet, not all workers opposed the court's decision. A number of them instead protested against the company, the government, and the municipality's absurd decades-long silence in response to obvious environmental and public health hazards. Together with a number of other citizens' organizations, these workers claim that working-class people have a right to breathe clean air, drink clean water, and live in a safe environment. They firmly contest the false dichotomy between health and work, silently implying the sacrifice of the environment, and call attention instead to the criminal responsibilities of the company in disregarding environmental regulations.

Taranto's dilemma exemplifies a crucial issue involving the definition of a possible transition to a more sustainable economy in a way that could be acceptable to, even actively shaped by, workers and workingclass communities. Sustainability policies aimed at social justice must be based on new and convincing forms of articulation between labor and environmental issues. Environmental history can help in this endeavor by offering an informed and reflective view of the ways in which the work/environment conflict has been historically shaped and of how this conflict has in turn shaped the environment and people's lives.

This article offers a tentative framework for such analysis by pointing to three arenas where the connections between work and environment can be investigated. The first presents the landscape as reflective of past human labor. The second examines the workplace and its relationship with the local community. The third focuses on working-class and labor environmental activism. The article builds on research developed by both environmental historians and other scholars, referring to different scholarly traditions and focusing mostly on three contexts: Italy, 
Latin America (with special attention to Brazil), and the United States. By bringing these disparate literatures into a transnational dialogue, I aim to transcend the confines of national histories and historiographies in the hope that these encounters will cross-fertilize the research field and prompt new conversations on places and cultural contexts beyond those discussed here.

\section{SEEING LABOR THROUGH NATURE}

Historical materialism is an excellent starting point for such reflection. Marx and Engels viewed labor as part of nature, in that they saw workers as natural beings exercising their physical as well as mental abilities on external nature. Labor and nature thus constituted each other in a dialectical, metabolic relationship. ${ }^{2}$ The alienation of humans from labor was part and parcel with their alienation from nature, a product of enclosure and dispossession (so-called primitive accumulation) within the capitalist system. Marx's critique of capitalism is consistent with an ecological critique: capital organized the exploitation of nature (the natural conditions of production) through the exploitation of human work-a view that passed on to the Frankfurt school and that has also been shared by many environmental historians. ${ }^{3}$

This aspect of Marxian thought has influenced scholars interested in developing a holistic approach to society-nature relationships. In his 1980 essay "Ideas of Nature," British literary critic Raymond Williams criticized the triumphalist view of the Enlightenment and industrial eras that asserted the separation of humans from the nonhuman world. Williams argued instead that human and nonhuman nature are inextricably linked through the labor process, stating, "We have mixed our labour with the earth, our forces with its forces too deeply to be able to draw back and separate either out." ${ }^{\prime 4}$ More recently, ecoMarxist scholar James O'Connor suggested that labor's role in the history of nature is that of a partner in a common story of domination and exploitation. What nature and labor share, he argued, is their being treated as commodities by the capitalist system. O'Connor invited scholars to see the history of labor as an important component of environmental history, noting that "the more that (humanmodified) nature is seen as the history of labor, property, exploitation, and social struggle, the greater will be the chances of a sustainable, equitable, and socially just future." 5

Similar views have been adopted in a number of environmental history narratives. A notable example is Richard White's 1995 essay "Are You an Environmentalist or Do You Work for a Living?" There he noted that two ideas were deeply rooted within US environmentalism: first, that work is the main cause of environmental destruction, and, second, that an Edenic relationship (of whites) with the American environment had been possible at the time of first contact and was still 
possible to recapture. White argued that both ideas were rooted in Judeo-Christian culture that viewed labor as originating in sin and coinciding with the expulsion from Eden, where nature is a garden and a place of leisure, to Earth, where nature is degraded into a wilderness and a place for sweat and fatigue. Contrary to this vision, White contended that work-not leisure-is the experience historically most significant to the human understanding of nature and that American environmentalists need to see nature as a place for human work and living. His study on the transformation of the Columbia River, The Organic Machine, applied a view of environmental change as a coproduction of humans and nature's work. ${ }^{6}$

Along similar lines, Italian scholar Piero Bevilacqua views nature as an active historical agent, cooperating with labor in the creation of wealth. His 1996 book Tra Natura e Storia (Between Nature and History) presented an ecological critique of classical economic thought, including Marxian political economy, centered on a labor theory of value, which he stated was reducing nature to a passive object of manipulation. Such thinking, Bevilacqua argued, negatively affects our ability to see nature as an agent other than society and with its own economy, and thus prevents a true understanding of the interaction between the two. In his history of modern Italy, Bevilacqua consistently describes nature as a partner with labor in co-constituting landscapes and social formations. Tra Natura e Storia describes various configurations that the work-nature relationship had taken in the nineteenth-century Italian landscape, each corresponding to different land property assets and agrarian labor relationships. ${ }^{7}$ In so doing, Bevilacqua builds on a tradition of Italian scholarship that started with Emilio Sereni's 1961 history of the Italian agrarian landscape, Storia del paesaggio agrario, a work that enjoyed international resonance in its field.

Conceived as a counterpart to contemporary histories of the French countryside by Annales scholars and based on visual representations (primarily paintings and maps), Sereni's book convincingly showed how the evolution of the Italian landscape since pre-Roman times was the result of the dynamic interaction of environmental conditions (climate, soil, altitudes, etc.) with different forms of socially organized work. In Sereni's account, generations of Italians had reworked the landscape they had inherited, with its resources and constraints, not only according to the economic, political, technical, and cultural conditions of the time, but also in accordance with a consciousness of the place, i.e., the aesthetic perception and the knowledge that people gained of the place by living and working on the land. In short, Sereni had adopted a view of the landscape as "past human labor" incorporated into the soil. ${ }^{8}$

Although both Sereni and Bevilacqua can be considered Marxian historians, such a view of the agrarian landscape is not peculiarly Marxian. In fact, the perception of Italy as an "artificial homeland" - a land made inhabitable through work-and of its landscape as an "immense 
repository of human labor," was formulated in the mid-nineteenth century by the agronomist Carlo Cattaneo, based on the historical experience of Lombardy's Po River plain and in dialogue with contemporary observations by the English agronomist Arthur Young. ${ }^{9}$ Nowhere was such a view more convincing than in the case of bonifica agraria, the drainage-and-improvement schemes repeatedly pursued since the early modern era. The bonifica thoroughly reconfigured the peninsula-particularly the Po plain, Tuscany's lowlands, the Pontine Marshes, and large parts of the South-between the nineteenth and twentieth centuries. Before (and even partly after) the introduction of the steam-powered pump, draining the land had required long, painstaking manual work carried on with buckets, shovels, and spades, with the help of horses and mules. Thousands of laborers from throughout the region worked in highly unhealthy conditions, waist-deep in water for most of the time. Many were destined to get ill and even perish from malaria, typhoid fever, or merely fatigue and malnourishment. The history of the peninsula itself, its geomorphology, is thus profoundly enmeshed with that of the people who gave the land a new shape by opposing their bodily force to that of the current, struggling against gravity and erosion, and finally reworking the course of its rivers. ${ }^{10}$

What must be recalled, however, is that the bonifica had military overtones. The conquest to reclaim land from water entailed harsh discipline and exploited profoundly unequal social relationships. Although performed under different social configurations and political regimes (from enlightened reformism to agrarian capitalism, fascist rule, and postwar development politics), the bonifica always rested on one crucial element of the Italian agrarian landscape: the abundance of cheap labor, whether local or forcibly relocated from other regions. Bonifica was thus synonymous with the power of redesigning nature by means of controlling labor. ${ }^{11}$

Like the Italian bonifica landscape, but on a much ampler scale, California's modern landscape reflects hard work performed under conditions of social domination, as both environmental and social historians have shown. Don Mitchell suggested that California's twentieth-century landscape is inseparable from the oversupply of itinerant labor, which was socially produced to make agriculture a highly profitable enterprise. ${ }^{12}$ Likewise, Douglas Sackman described California's Orange Empire as a form of "hegemony over people and places," obtained not only by recruiting its labor force from across the globe but also by extending its sphere of influence through advertising. Its promotional language created a vision of the citrus industry "as a spontaneous production of Eden, bearing no traces of workmanship" - and especially of its working and living conditions. ${ }^{13}$

The Edenic language can be used not only to conceal, but also to sublimate the human work embedded in landscapes. In No país das Amazonas (In the Country of the Amazons, 1921), Portuguese director Silvino 
Santos portrayed the wonders of Amazonia as a frontier garden rich in every kind of natural wealth and diversity. He did so not through the language of aesthetic contemplation, but that of work. The film displays an incessant movement of men, women, animals, and instruments in the act of working and reworking the place. The connotation of such work was largely positive. It was the ability of humans (both whites and native peoples, although in different ways) to alternatively make use of and contrast the forces of nature, typically exemplified by the currents of the Amazon River, in order to extract its resources and carve a space for themselves in the region. The film celebrated human work at the same time and by the same means through which it celebrated nature. Of course, Santos came after almost four centuries of European colonization of the region; thus, what he filmed was not a "native" environment. ${ }^{14}$ Nevertheless, he demonstrated that even a quasi-wild and diverse landscape such as the Amazon could be celebrated as a co-product of human and nature's work. ${ }^{15}$

No país das Amazonas provides us an organic appreciation of the work-nature relationship, one that seems to contemplate the possibility of harmonious cooperation, of coproduction. It gives an image of nature and human work as complementing each other: nature is not an untamed wilderness, even though its forces, beauty, and wealth are still unspoiled; work is not a destructive force, even though humans are able to penetrate the jungle and get their hands on the incredible richness that comes from it. Perhaps such vision is one typical of frontier landscapes in an early stage of exploitation (when nature still appears as the ruler), and it serves to encourage human settlement and the business that goes with it. But visions such as this are destined to endure, even when the landscapes and social relationships they represent have long gone, as it is with the rubber industry that set the stage for large parts of Santos's movie and generously funded his enterprise. They express an idea of harmony that overcomes classical dualisms of Western culture between Eden and Earth, of nature as leisure versus nature as sweat and fatigue, and so they function as what Carolyn Merchant calls "recovery narratives." ${ }^{16}$ No país das Amazonas represents a recovery narrative of the Amazon in times of early frontier capitalism.

Of course, a good environmental history narrative can only take this as a starting point. Clearly, celebrations such as that of Santos's movie served to conceal the unequal and exploitative labor relationships that governed the remaking of Amazonian landscapes, and of course what came to be celebrated in the film is not nature per se but the resources it yielded to human ingenuity and hard work. Furthermore, the work that features in the movie as a co-protagonist with nature is that of racially discriminated migrant workers, debt peons, and enslaved indigenous people. Blatant violations of human rights, mass deportations, and slaughter were not uncommon - and they are still reported in some cases todayas a means to coerce local labor, particularly that of indigenous 
populations who better knew the nature of the place, into working for capitalist enterprises, both national and foreign, in the tropical environment. ${ }^{17}$ It is worth remembering that roughly thirty thousand Putumayo people were reported to have died while working in rubber extraction for the British-Peruvian Amazon Company of Júlio Cezar Araňa in the first decade of the century. ${ }^{18}$ No país das Amazonas was profoundly enmeshed in those power relationships. In fact, Araňa funded Santos's professional film training and then hired him to produce a document that would capture Araňa's version of the story-one where labor and nature were celebrated instead of annihilated. ${ }^{19}$ And yet the film does represent human work as a co-constitutive element of the natural landscape, and in so doing it gives us the opportunity to go beyond the misconceiving and silencing of its own narrative to wonder what it truly meant to live and work in the early twentieth-century Amazon.

Viewing landscapes as products of past human labor is a first, crucial step for an environmental history of work. Raymond Williams noted how "A considerable part of what we call natural landscape. . . is the product of human design and human labour, and in admiring it as natural it matters very much whether we suppress that fact of labour or acknowledge it." ${ }^{20}$ The extent to which labor is part of the landscape varies with geography as much as with history. In any case, removing the image of work from the landscape has produced the dominant vision of nature in the Western/industrial culture that has led to romantic views of "the environment" as something to be protected from work and, therefore, from working-class people, even though environmental historians and political ecologists have documented that private property, the market, and state control, not labor, have been the main forces behind resource exhaustion. ${ }^{21}$

Romanticizing people's perceptions of and relationships to nature through work is also problematic, as Thomas Andrews's study of the "workscape" of coal mining in Colorado exemplifies. As with the bonifica works of the Pontine marshes and elsewhere, Colorado's coal workers experienced a "cartography of risk," punctuated with explosive gases, invisible coal dust, and falling rocks. That such danger was a result of complex combinations of social and natural forces-the political economy of fossil fuels and of corporate mining, in this case-on which individual workers had little control, also formed a crucial common perception for Colorado colliers who developed intense and radical forms of political mobilization in the attempt to turn that perception into revolution. ${ }^{22}$

A similar story of political consciousness and revolutionary action arising from the experience of working in dangerous extractive activities is that told by Myrna Santiago on the oil fields of northern Veracruz, where a violent remaking of environmental, working, and living conditions produced what she called the "ecology of oil." According to Santiago, the ecology of oil had come out of three interrelated processes, 
all together reconfiguring the relationships between nature, labor, and social power in the local landscape: first, the dispossession of indigenous communities and of local settlers-farmers; second, massive environmental alterations, including forest and river habitat destruction, in order to make space for oil extraction operations; and third, the imposition of new, racially discriminating, labor relationships. This triad of socioecological change was accomplished by the new liberal and probusiness elite of the late nineteenth century, who shared with foreign investors an ideology of progress based on the mastering of both labor and nature. For Mexican manual workers and their families, who occupied the bottom of the labor hierarchy, working and living in the Huasteca oil fields became a daily struggle against the hazards of the weather, tropical diseases, fire, and chemical and bacterial contamination. Lacking any substantial protection, they suffered a heavy toll for the so-called development of the Mexican oil industry. As a result, Santiago notes, the landscape of Huasteca's oil fields is literally lined with the corpses of racially discriminated local workers buried alongside pipelines. ${ }^{23}$

But this is not the end of the story, because the same oil fields turned Mexican workers into politically conscious and active citizens in the form of "strikers, trouble-makers, risk takers and union men." ${ }^{24}$ Mexican oil workers realized that property-that is, control over both the land and the labor process-mattered in determining the sustainability of their work experience in the tropical forest. In fact, Santiago argues, the 1938 nationalization of the oil industry can be considered partly a result of three decades of workers' struggles for healthier and safer work conditions. Unfortunately, they came to learn that states do not always perform better than private industry in terms of environmental safety and human health. Even though the publicly owned PEMEX made notable improvements, including recognition of a number of occupational diseases, prevention trainings, and medical treatments, production targets still remained more important than the preservation of workers' bodies or of the forest ecosystem. Moreover, the scaling up of oil operations implied the extension of oil risk from mostly workers to entire communities. Thus not much changed in terms of labor-nature relationships, insofar as oil operations still rested on the destruction of the ecosystem and the impairment of living conditions for human and nonhuman life in the region.

In sum, the work-nature relationship that landscapes embody is crucially mediated by social relations. Be it in Italy's drainage-improvement schemes, in California's agrarian landscape, in Colorado coalfields, or the tropical "frontier," controlling labor has created new socio-natural orders that are profoundly unhealthy for both the land and the people. Adaptation and cooperation with nature have been replaced by attempts at domination and control, with often unwanted, unforeseen, and irreversible consequences. It is not work per se, therefore, 
but the social meaning and ends of work that make the difference in the sustainability of society-nature relationships.

\section{THE ECOLOGY OF WORKPLACE AND COMMUNITY}

Another important step in the environmental history of work comes from placing the workplace center stage in our narratives and understanding it as an ecological system. This approach was suggested by Arthur McEvoy in a 1995 article, noting that, from the vantage point of the shop floor, "Ecology points to an analysis of health and safety in terms of the interaction between a number of systems: the worker's body and its maintenance, the productive processes that draw on the worker's energy, and the law and ideology that guide them." Not only the workplace, but also workers' bodies should thus fully enter environmental history narratives as meta-texts where the political ecology of industrial societies had been written. ${ }^{25}$

An important contribution in that sense was given, again in the United States, by Christopher Sellers's Hazards of the Job, a work that marked a turn in the literature by bridging the history of the workplace with that of environmental science and environmentalism. The book showed how US and European workplaces had been important spaces for knowledge production about human and environmental health and for professional coalitions pushing toward regulation of industrial hazards. Not only has work been extracted from workers' bodies in the course of the industrial era, but so too has knowledge. The branch of medical science known as industrial hygiene developed out of extracting information from workers' bodies and observing their reaction to a variety of risk factors in the course of their work life. This kind of science evolved in Europe and the United States between the last decade of the nineteenth century and the first half of the twentieth, and it reached a wider significance for the environmental movement through Rachel Carson's Silent Spring, which amply relied on research from physicians and industrial hygienists. It was that science that first began to draw the boundaries between normality and abnormality, acceptable and unacceptable limits of exposure and contamination. The environmental movement of the 1960s, according to Sellers, started from the criteria and definitions central to industrial hygiene to attack pollution. ${ }^{26}$

Studies of different workplaces have depicted them as typically unhealthy environments, where illness is normalized and workers bear the marks of the "treadmill of production. ${ }^{27}$ Here environmental historians have profitably met with social historians of medicine and with scholars in occupational health, broadening the spectrum of possibilities for interdisciplinary dialogue beyond that of the natural sciences. ${ }^{28}$ Workplaces, however, are far from being a typical subject of environmental 
history narratives, and especially so when it comes to industrial plants, where environmental historians seem particularly reluctant to enter. Yet the ecological dimension of modern industry is written in the flows of toxins emanating from the workplace to the environment and the human body through air, water, the biogeochemical cycles, and the food chain. Before encountering the living environment outside, industrial toxins meet workers' bodies, which represent the biological dimension of the industrial workplace. Historically, such encountering between micro-particles and workers' bodies gave rise to important forms of political and ecological consciousness, and to organized action.

A case in point is the story of labor environmentalism in Italy. Here, a vision of ecology as having to do with the industrial manipulation of nature and human labor became the theoretical basis for a consistent wave of radical leftist environmentalism. In What Is Ecology: Capital, Labor and the Environment, first published in 1977, scientist Laura Conti posited organic chemistry and carcinogenic, mutagenic, and reproductive risk at the center of a plastic explanation of ecology as the interconnection of all living and nonliving matter. Conti's definition of ecology was very similar to that of another scientist who convincingly argued that petrochemicals pose a terrible menace to all living creatures including humans: the American biologist Rachel Carson. Unlike Carson, however, Conti was also a politician. She was an elected councilor for the Communist Party in the Milan district between 1960 and 1970, then in the Lombardia regional government between 1970 and 1980, and a deputy in the national parliament from 1987 to 1992, where she worked at the Agriculture Commission. ${ }^{29}$ She never disentangled her commitment to environmental issues from her political engagement; the two were linked in a unique vision of society-nature relationships. In fact, she was the first in Italy to define political ecology as "the study of how social relationships within the human species influence the natural world and other species." ${ }^{30}$

Conti, however, was not alone in her search for ecological Marxism in Italy. In the fall of 1971, at its yearly cadres' school in Frattocchie, the Italian Communist Party held its first national meeting on the theme "Man, nature, society," emphasizing the need for the party to consider the environment a working-class priority. ${ }^{31}$ This opened the possibility for a left-wing environmentalism to take form in the country. Legambiente, today a highly established environmental organization, arose in 1979 as a subsection of the Communist Party's cultural and recreational activities, and Conti figured among its founding members. ${ }^{32}$ The rise of this Italian working-class environmentalism should be understood within the context of two decades of massive industrialization and environmental transformation, at the end of which the country's public opinion (not only the leftist one) was ready to acknowledge the existence of an "environment" problem. ${ }^{33}$ 
The event that marked the birth of a new ecological consciousness in the Italian Left was the Seveso accident. On July 10, 1976, the explosion of a chemical reactor at the ICMESA plant located near the town of Seveso, in Lombardy, caused a cloud of dioxin to rise over the town and its rural hinterland, directly affecting a population of ten thousand. Of all industrial disasters during the Italian economic boom, the one in Seveso spurred the greatest attention on the part of the government and the national and international media, leading the European parliament in 1982 to pass the first European Union law on industrial hazards, known as the Seveso Directive. As a regional councilor, Laura Conti found herself at the forefront of the battle for citizens' "right to know" and participative science that characterized the political relevance of the accident. ${ }^{34}$

Conti's battle for public access to information and decision making in Seveso revealed one interesting aspect of the political definition of risk: in explaining how the maximum acceptable concentration (MAC) of dioxin had been established, government officials declared they had relied on "US standards for farm work," a statement for which Conti could find no evidence despite great efforts. ${ }^{35}$ Along with other Italian labor physicians, Conti accepted the idea of using MAC levels of dioxin in occupational health science as a basis for delimiting Seveso's "unsafe zone" and especially for defining the cleanup operations. Unfortunately, this was not the position adopted by the Italian authorities, either at the local or the national level. And, moreover, this was not what local people wanted. Whether they were misinformed or genuinely convinced that the risk was worth taking, Seveso residents wanted to stay home as much as possible. More, they longed for reassuring answers that spared them the painful choice of staying or leaving, having children or aborting. They clearly manifested their attachment to the place where they lived and worked, even though many of them were only first-generation migrants to that place. The Seveso experience added to Conti's vision of ecology a sense of the role of culture and symbolic meaning - places and people's connection to them must find their way into the science of ecology, she concluded. ${ }^{36}$

Seveso was a laboratory experience for what urban ecologist and communist militant Virginio Bettini termed "class ecology," an approach theorized in the course of community meetings featuring left-wing scientists (Barry Commoner among them) that the communists organized in Seveso with the intent of mobilizing local people against corporate and government cover-up. The "class ecology" approach was centered on industrial pollution as the most compelling and politically relevant aspect of the environmental crisis and on working-class people as its primary victims. Bettini claimed, "Society's debt towards nature is a debt towards the working class." ${ }^{37}$ It is not clear, however, how far the working class, and even the workers of the ICMESA plant, actively participated in Seveso's "popular scientific committees" organized by the 
communists, and on what positions. Despite their generous efforts at helping local people to struggle for their rights (and not only for monetary compensation), leftist activists in Seveso met with diffidence and even open resistance, also significantly related to their proabortion stance. $^{38}$

The problem with the "class ecology" approach was that, however ideologically correct, it met with the unexpected opposition of working-class people. As Laura Conti came to realize, "People had never been put in the condition to understand that, to have a healthy environment, it is necessary to sacrifice something: everything has always been done to get more salary, more cars, more highways, even -in the best cases-more hospitals and schools, but almost nothing to get cleaner air, cleaner water, safer food. At this point, why expect that all of a sudden the Brianzoli [the people from Brianza, i.e., the Seveso area] recognize that living in a healthy land is worth a mass exodus?" Conti directed her critique against her own party, which had never taken a real stance toward the protection of nature. She decried the stigmatization of Seveso residents as "immature" or "stubborn" and concluded, "None of us has the right to criticize the Brianzoli." 39

The story of Seveso holds many significant implications for environmental historians. First, it tells us that a good environmental history of work should take into account the workplace/community link. Not only in the sense of the national community or of broader communities such as those of parties and unions, but the local community, where people have faces and names, are family or neighbors, and where they share the same air, soil, and water. In other words, a good way of connecting work and environmental narratives is choosing working-class communities-including the workplace, workers, their families and neighbors, and the local landscape-as the subjects of our stories, for here it is that all the complexities and contradictions of the worknature relationship come into play.

Second, working-class communities are far from being unified social entities entirely corresponding to theoretical definitions of their class identity, interests, and behavior. Nor does working-class environmental consciousness entirely coincide with the politics of Labor parties or unions. Although the theoretical effort on the part of the Italian Left to make the environmental question a class issue may sound correct, the environmental consciousness of Seveso residents retained unexpected motivations, such as the attachment to the place and the desire to preserve the local landscape as it was-contaminated by some invisible chemical substance.

Other environmental history studies have made this point comparatively clear. In Chad Montrie's To Save the Land and People, Appalachian people opposed coal strip-mining, outraged by the devastation of the land, the loss of resources such as soil, fish, and game, the peril of landslides, and the massive alteration of the local landscape. However, 
Montrie also shows how some of the conflict took place between deep miners and surface miners, the first accusing the second of being outsiders who did not care for the land they were ruining. The United Mine Workers also took on an ambivalent position. It initially supported the regulation of strip-mining because, unlike deep mining, it was a largely nonunionized activity. The union, however, was not a monolith. Different positions on the strip-mining controversy existed among miners and union leaders and came out through internal conflict at different moments of the story. Labor was thus an active part in the stripmining controversy. ${ }^{40}$

The concept of "workscape," as formulated by Thomas Andrews, might prove an innovative instrument for investigating working people's environmental consciousness. One important aspect of that concept, for example, is that of human-animal relationships. Be it the rats befriended by Colorado colliers as daily companions in their mining rooms and as living warning systems against imminent danger, or the mules they had as helpers and with whom they had to establish labor relationships based on a difficult mix of domination and cooperation, or the seabirds with which Hawaiian guano workers shared their own workscape, as shown by a recent article by Gregory Rosenthal, animals have played an important role in humans' relationship to nature through work. ${ }^{41}$ In the Seveso accident, as well as in innumerable other cases of chemical or radioactive contamination, pets, barn animals, birds, and other creatures that share their living space with that of humans, are typically the first to present the effects of intoxication, thus signaling Rachel Carson's message that the fates of human and nonhuman beings are inextricably related through the sharing of common life-supporting systems. More than that, they are related through what eco-critic Stacy Alaimo calls transcorporeal bonds, made of material, cultural, sentimental, and symbolic links among which labor relationships should also figure. ${ }^{42}$

Andrew Hurley's concept of environmental inequalities also helps to elucidate working-class connections to the environment. In his book on Gary, Indiana, Hurley offered a detailed and nuanced portrait of the many peculiarities of working-class experiences of nature and of environmental change. ${ }^{43}$ Others have followed his lead, showing that working-class communities elaborate particular ways of dealing with the environment and with environmental change, mediated by their labor and by the social relations of production that take shape in the local space. These relationships generate unique forms of "ecological consciousness" based on some combination of work experience and experience of place, mixed with beliefs, traditions, and institutions of the culture of which the workers are a part. Additional factors that may affect workers' ecological consciousness are related to personal identity and life experience, such as gender, age, race/ethnicity, and family history, to elements such as personal skills and one's position in the 
local labor organization and employment status, or whether one lives, or is born, in the place where he or she works.

Despite many contingent, internal stratifications and differentiations, however, working-class communities do share common experiences and often develop a strong sense of belonging and identity based on some form of control over the work process, its social meaning, and its scope. They thus develop their own perception of the work/environment tradeoff that shapes their lives and the places in which they work and live. Their own bodies and mental capacities, as well as those of their families, are at stake in the continuous transformation of the local environment. They feel partially responsible for such environmental change, viewing it as a bargain they have to make in exchange for survival. Such bargains are often overly simplified as jobs versus nature, which obscures the nature and the diversity of environmental activisms that develop from working-class ecological consciousness.

\section{WORKING-CLASS ENVIRONMENTALISM(S)}

To find alternative answers to the false dilemma of jobs versus the environment as played out in Taranto and elsewhere, we should start examining the many occasions in which working-class movements have encountered environmental movements, generating various forms of "labor environmentalism." Although journeying through workingclass or labor environmentalism is quite uncommon for environmental historians, there are places (both academic and physical) where this has been done successfully, especially in the last decade. Undoubtedly, one such place is the United States, where the picture of people's environmentalism, to use an expression from Chad Montrie's recent book, is now articulated and nuanced enough to give us much material for comparative reflections. ${ }^{44}$ We will describe a few examples of labor environmentalism in Italy and in the Brazilian Amazon, highlighting differences and similarities that speak to the possibility of a true dialogue among scholars of the work-environment connection.

Popular environmentalism in the United States has a long history, as Richard Judd's 1997 work on the origins of US conservation demonstrates. Judd pointed to popular perceptions of nature by the "common people" of New England as "neither conservationist nor anti-conservationist," as we define these terms today, but as "a complicated mix of Christian theology, practical wisdom, economic incentive and secondhand natural history." Without idealizing or romanticizing such popular environmental culture, Judd's work signaled the importance of understanding the contribution it had given to environmental law and policy, for "to ignore this perception, to wave it aside in the battle to protect the environment . . . is to court disaster." ${ }^{\prime 5}$ Similar insights can be found in Gunther Peck's 2006 article on labor in US environmental history, which posed the question of how the experience of the 
commons in nature-and that of alienation—had shaped the history of human work. Another important suggestion coming from the article was that of looking at the forms of nature's utopianism harnessed by the British and North American labor movements since the early modern period, in order "to make radical critiques of capitalism, landlordism, and slavery." ${ }^{46}$ Lawrence Lipin's study of the "progressive conservation" that came out of working-class environmental culture in early twentieth-century Oregon and Chad Montrie's Making a Living: Work and Environment in the United States further reveal ways that workers attempted to mitigate environmental decline. ${ }^{47}$

A number of authors also have addressed the relationship of labor and leftist culture with the new environmentalism of the postwar era, focusing on the contributions that unions and the labor movement in general have made to environmentalism. According to Scott Dewey, it was during the early postwar period that awareness of potential health risks from pollution "became quite advanced in US working class people in comparison to that of their fellow citizens." During the 1950s, the United Auto Workers, through their president Walter Reuther and vice president Olga Madar, pressed the government for the regulation of gasoline emissions, even if this meant losing a number of jobs. In Madar's opinion, workers were first and foremost American citizens and "neither they nor their children develop any immunity to automobile exhaust pollutants or any other." ${ }^{\prime 48}$ In the following two decades, oil, chemical, atomic, steel, and farm workers' unions coalesced with some environmental organizations, leading to the passage of some major pieces of environmental regulations, such as the Clean Air Act of 1970 and the Clean Water Act of 1972.

In Forcing the Spring, Robert Gottlieb showed how the role of health professionals, coming from the ranks of the student, feminist, environmental, and radical Left movements, was crucial in soliciting those reforms, supporting the labor movement in their implementation and pushing mainstream union organizations and their leaderships toward an inclusion of environmental protection in their grievances. As a leader of the Oil, Chemical, and Atomic Workers International Union, for example, Anthony Mazzocchi was instrumental in the passage of the Clean Air and Clean Water Acts. Likewise, Cesar Chavez and the United Farm Workers first raised the issue of pesticide poisoning in the early 1960s as a unified struggle in defense of both workers' and consumers' health. ${ }^{49}$ As Robert Gordon argued, between the late 1960s and early 1980s, "workers, environmental activists, and union leaders across the country concluded that the spread of hazardous substances in the workplace and the spread of pollution in the environment represented two aspects of the same problem," and the cultural premises for organizational alliances between environmental and labor movements were laid out. ${ }^{50}$ 
The 1970s were a fruitful period for labor/environmental alliances in the United States, as exemplified in the experience of the Environmentalists for Full Employment groups, the Urban Environmental Conference, and Ralph Nader's and Barry Commoner's networks, among others. Nevertheless, according to Gottlieb, for environmental organizations, workplace and social justice issues remained external to their mission, just as the labor movement "remained bound by union acceptance of the structure of industry decision making." ${ }^{51}$ Furthermore, as Brian Obach has argued, the relationship between labor and the environmental movements grew more conflictual during the 1980s, as a result of the political turnover of the Reagan era. ${ }^{52}$ At the grassroots and local level, however, a number of cases have been documented in which coalitions continued well into the 1980s and 1990s, extending to the present. ${ }^{53}$ At that point, working-class environmentalism was not just a matter of efforts at coalescing labor and environmental organizations, but it converged with grassroots and community struggles put forward by what came to be known as the environmental justice movement.

The environmental justice movement in the United States defines the environment as the place where "we live, work and play" (emphasis added). In fact, as Robert Bullard pointed out in Dumping in Dixie, work has been a potent mechanism of environmental injustice and racism, considering that the most unhealthy low-paying jobs are those most likely to be filled by African Americans and Latinos. He wrote, "Requiring people to choose between jobs or the environment is inherently unfair. The solution to this dilemma lies in making workplaces safe for workers. Anything short of this goal places workers at an unfair disadvantage. ${ }^{54}$ Largely reputed as the founding text for environmental justice studies and activism, Dumping in Dixie was built on an ample recognition of the importance of "job blackmail" as a structural cause for the production of environmental injustice. Labor unions, however, rarely figure in the book, as the leadership for environmental justice activism had evidently shifted to different actors.

This move from union to community activism as the privileged terrain where grassroots environmental struggles are fleshed out has been interpreted in social science in terms of a shift from the conceptual framework of "class" to that of "subalternity." ${ }^{55}$ In the last decade, "environmental conflict" has become an important way to describe subaltern environmentalism or so-called environmentalism of the poor, spurring a new array of social science research, also involving and intriguing environmental historians. ${ }^{56}$ Environmental justice, subaltern environmentalism, environmentalism of the poor, and environmental conflict are all useful concepts to understand various typologies of struggles coming from working-class people and involving environmental costs and benefits, both in the urban and in the rural space. These struggles often contain an unobserved or undertheorized link between labor 
and environmental concerns. Most social science research on environmental conflicts pays attention to community agency-sometimes assuming the term acritically-as opposed to government or corporate agency, while overlooking the role that workers play in such conflicts, or rather the relevance of work in mediating people's understanding of the environmental issues at stake. Paradoxically, work and its complex relationship to environmental concerns is probably the less known aspect of environmental justice struggles and of environmental conflicts.

And yet work is and has always been relevant to those struggles, for the simple reason that "subaltern" people, racially discriminated people, or "the poor" are typically also working-class people, that is, people who occupy the lower ranks of the labor hierarchy, making a living out of the most dangerous and most unhealthy jobs while also living in the most polluted places. "In every way," environmental sociologist David Pellow has written, "the workplace is an environmental justice issue. ${ }^{\prime 57}$ In the United States as elsewhere, work has been a relevant component of environmental justice struggles since the beginning but in ways more complex and contradictory than expected. As Pellow's study of the garbage industry in Chicago demonstrated, for example, recycling programs supported by environmentalists and even environmental justice organizations often turn into extremely hazardous jobs and labor-unfriendly policies, oppressive of workers' rights and culture. Anti-unionism, in fact, features as a main driver of the book's narrative; unions only figure as either suppressed or absent actors. ${ }^{58}$

Union activism, however, is not completely absent from environmental conflicts and justice, or from subaltern environmentalism. In some cases, in fact, union organizations and individual leaders have played a crucial role in defining the terms of the conflict and setting out the possibilities of change. To find what is probably the most compelling story of labor environmentalism, one that reached and still holds global relevance, we must once again turn to the Amazon region, particularly to the state of Acre, Brazil. Here, in the early 1980s, a landless workers' movement for the protection of the forest grew out of rubber tappers' struggles against powerful lumbering and ranching interests, and it led to the passage of an important piece of legislation, the "extractive reserve" bill of $1990 .{ }^{59}$ The "extractive reserve" idea represents a very interesting possibility to overcome the work/nature dichotomy typical of Western culture. In fact, it is a good means of overcoming the West/non-West cultural dichotomy itself, for it is inspired, on one hand, by indigenous people's relationship with the land and, on the other hand, by the 1988 Brazilian Constitution that acknowledges and protects "traditional" populations' rights to their ancestral lands. The extractive reserve idea put together the defense of different noncapitalist forms of the worknature relationship: collective use rights (as opposed to individual 
property rights); land-based cultural identity and livelihoods (as opposed to forest encroachment and forced evictions); and wild-fruit gathering and biodiversity conservation (as opposed to monoculture and resource exploitation). In all cases, the forest gets to be preserved not as a place for leisure or for scientific investigation, but as a place for working and living-indeed, as what allows the local human communities to survive and maintain their culture. Be they indigenous or caboclos, the extractivistas (rubber tappers but also wild fruit gatherers and fishers) are those who actively protect the forest from encroachment and destruction; the forest needs those people as much as the people need the forest.

According to anthropologist Mary Allegretti, the rubber tappers' movement can be considered a new social movement, in the sense that it encompassed objectives of different nature, at once social, economic, cultural, and environmental, linked together by a coherent worldview and political project. Their actions span from primary education and adult literacy to biodiversity conservation, from access to livelihood resources to the protection of cultural identity, from health to transportation means. Taken together, all these things were aimed at allowing people to survive and even thrive in the forest environment. Moreover, the seringueiros adopted innovative forms of both organization and struggle. The most typical was the empate (first occurred in 1976), an action in which men, women, and children "would stand unarmed in the way of tree cutters and their equipment, blocking the destruction and appealing personally to the peons as people of the same social class." As Biorn Maybury-Lewis writes, "It was a nonviolent, communitarian, educational, and consciousness-raising approach to struggle, where all involved on both sides went away thinking that 'this is different, this is special."'60

However, like older social movements (and particularly those involving labor), the seringueiros had to confront the violence of police repression and assassinations of union activists. Among movement leaders who came to be prosecuted under national security law were Ignacio Lula da Silva (future president of Brazil, then leader of the metalworkers union) and Francisco "Chico" Mendes, a local leader of the Sindicato dos Trabalhadores Rurais and founder of a national rubber tappers' council. Mendes was assassinated in 1988, and his death came to have a large international resonance that served to push the Brazilian government to pass the "extractive reserve" project into law. The principle of nature conservation through sustainable use on the part of local populations was then recognized at the global level through the International Convention on Biodiversity of 1992. This represented the highest acknowledgment, for environmental policies, of the "past human labor" that is embodied in landscapes and, at the same time, of the possibility that a more sustainable future rests on the human ability of "saving" nature through work. 
In other cases, however, labor unions have maintained a much more detached attitude toward environmental issues or even openly opposed grassroots environmental action at the local level. Still, this has not impeded workers' environmental activism. The Italian case is significant in this respect. Several important trial cases against large polluting companies, especially in the petrochemical and asbestos sectors, have been brought forward in the last forty years stemming from occupational health grievances. ${ }^{61}$ Typically, those struggles have been based on "popular epidemiology" studies, collecting evidence about workrelated cases of cancer among the laborers of those industries, but they have then become class actions-one might say "working-class actions" - involving workers' families and larger communities, including the neighborhoods around those factories, the urban population affected by air, water, and soil pollution, local fishing, sports, and environmental associations, women's organizations, and health professionals. Italian unions have followed a historical pattern somewhat similar to that highlighted for the United States: they have strongly supported environmental regulation, especially in the industrial sector during the 1960s and early 1970s, while adopting a much more reductive approach to workers' grievances during the economic recession of the late 1970s. In some cases, local unions have even aggressively boycotted environmental justice actions, practicing various forms of ostracism toward those members who supported them. Like the one taking place in Taranto today, those struggles have incorporated all the dilemmas and contradictions typical of the work-environment relationship in industrial societies, which makes them all the more interesting.

\section{CONCLUSIONS}

Like so many other working-class communities, Taranto's workers seem to perceive the environmental discourse as something alien to their world, not because they despise it (who is not an environmentalist, nowadays?), but simply because this is a choice that is not offered to them. Their democratic options and the exercise of their citizenship rights seem in fact to be limited by the position they occupy within the industrial order. In short, they do not seem to have a right to be environmentalists. Yet environmental histories of working-class people and movements seem to contradict commonsense assumptions about the work/environment conflict. Be it in the oil fields of the Huasteca or in the Amazon forest, in the Italian "industrial triangle" or in the mountains of Appalachia, working-class communities, union leaders, and individual workers have been historical subjects endowed with ecological consciousness and agency as advocates for environmental health and conservation. Their environmentalism, when and where this has taken an organized form, is simply different from that of the metropolitan middle class and of all 
those social groups whose subsistence does not depend on any specific agro-industrial activity.

Perhaps the answer to the work/environment dilemma may come from recent discourses of just transition, pointing at the injustice of shifting the cost of environmental cleanups on labor and invoking the right to compensation and the right to voice-that is, to selfdetermination on the part of working-class communities-as regards the shift to an environmentally sustainable economy. ${ }^{62}$ In order to build "just transition" policies, however, a first step is recognizing the historical role of work as the single most important interface between society and nature, and of working-class people as possible subjects of a more inclusive vision of how to "save the environment."

Stefania Barca is senior researcher at the Center for Social Studies of the University of Coimbra, Portugal. She is the author of Enclosing Water. Nature and Political Economy in a Mediterranean Valley (Cambridge: White Horse Press, 2010), recipient of the Turku Book Prize in 2011. She served as vice president of the European Society for Environmental History from 2011 to 2013. Her most recent research has dealt with labor environmentalism in Italy in the postwar era.

\section{Notes}

Research for this article benefited from EC funding under the Marie Curie Actions Initial Training Networks - FP7 - PEOPLE - 2011; contract No. 289374 - ENTITLE. The article also largely benefited from conversations and the exchange of ideas I have had the opportunity to enjoy with many people. Among them are Barbara Allen, Bob Bullard, Laura Centemeri, Marcelo Firpo, Joan Martinez Alier, Martin Melosi, Felipe Milanez, José Augusto Pádua, David Pellow, Myrna Santiago, Jim Scott, Chris Sellers, Lays Silva, Donald Worster, Angus Wright, and Marco Armiero. I am grateful to the two anonymous referees for their comments and suggestions, which I took into account as best as I could. A very special thanks to Lisa Brady for her invaluable assistance throughout the process of revision and editing, and for her appreciation and encouragement. While I have been lucky to interact with such a diverse and stimulating scientific community, all eventual mistakes are of course entirely mine.

1 On the Ilva story, see http://comitatopertaranto.blogspot.pt/ (last accessed October 20, 2012).

2 See John Bellamy Foster, Marx's Ecology. Materialism and Nature (New York: Monthly Review Press, 2000); 141-78; Paul Burkett, Marx and Nature: A Red and Green Perspective (New York: St. Martin's Press, 1999), 25-56; James O'Connor, Natural Causes: Essays in Ecological Marxism (New York: Guilford Press, 1998), 29-48. See also Howard L. Parsons, Marx and Engels on Ecology (Westport and London: Greenwood Press, 1977), 121-29, 136-45, 148.

3 See Carolyn Merchant, ed., Key Words in Critical Theory: Ecology (Amherst: Humanity Books, 1996): 1-27. On alienation from nature, see Foster, Marx's Ecology, 72 78. See also Richard Peets, Paul Robbins, and Michael Watts, "Global Nature," in Global Political Ecology, ed. Peets, Robbins, and Watts (Abingdon and New York: 
Routledge, 2011), 13-15. On Marxism and ecology, see also Carolyn Merchant, Radical Ecology: In Search for a Livable World (New York: Routledge, 2005), 14248, and Ted Benton, ed., The Greening of Marxism (New York and London: Guilford Press, 1996).

4 See Raymond Williams, "Ideas of Nature" in Problems in Materialism and Culture: Selected Essays, ed. Williams (London: Verso, 1980), 67-85. On the relevance of this essay for environmental history, see also William Cronon, "The Densest, Richest, Most Suggestive 19 Pages I Know," Environmental History 10 (October 2005): 679-81.

5 See O'Connor, Natural Causes, 48-71.

6 See Richard White, "Are You an Environmentalist or Do You Work for a Living? Work and Nature," in Uncommon Ground: Rethinking the Human Place in Nature, ed. William Cronon (New York: W.W. Norton, 1996), and White, The Organic Machine. The Remaking of the Columbia River (New York: Hill \& Wang, 1995). On nature as Eden, see Merchant, Reinventing Eden: The Fate of Nature in Western Culture (New York: Routledge, 2003), esp. chapter 1.

7 Piero Bevilacqua, Tra natura e storia. Ambiente, economie, risorse in Italia (Rome: Donzelli, 1996).

8 Emilio Sereni, Storia del paesaggio agrario italiano (Rome-Bari: Laterza, 1961; English edition: History of the Italian Agricultural Landscape, trans. with an introduction by R. Burr Litchfield (Princeton: Princeton University Press, 1997). On Sereni and his legacy in the Italian environmental history, see also Piero Bevilacqua, "Una scelta di campo. Dialogo intorno alla storia del paesaggio agrario italiano," Zapruder. Rivista di Storia della Conflittualità Sociale 24 (2011): 134-39.

9 Marco Armiero and Marcus Hall, "Il Belpaese. An Introduction," in Nature and History in Modern Italy, ed. Armiero and Hall (Athens: Ohio University Press, 2010), 1-14.

10 Piero Bevilacqua, "The Distinctive Characters of Italian Environmental History," in Nature and History in Modern Italy, 15-32. On the nineteenth- century idea of bonifica, see also Marcus Hall, Earth Repair: A Transatlantic History of Environmental Restoration (Charlottesville and London: University of Virginia Press, 2005).

11 On the forced migration involved in the bonifica of the Pontine marshes seen through a family saga, see, for example, the novel Canale Mussolini by Antonio Pennacchi (Milan: Arnoldo Mondadori, 2010).

12 Don Mitchell, The Lie of the Land: Migrant Workers and the California Landscape (Minneapolis and London: University of Minnesota Press, 1996), and Mitchell, They Saved the Crops: Labor, Landscape and the Struggle over Industrial Farming in Bracero-Era California (Athens: University of Georgia Press, 2012).

13 Douglas Cazaux Sackman, Orange Empire. California and the Fruits of Eden (Berkeley and Los Angeles: University of California Press, 2007), 152. On labor in the agricultural landscape of modern California, see also Linda Nash, Inescapable Ecologies: A History of Environment, Disease and Knowledge (Berkeley, Los Angeles, and London: University of California Press, 2006); Chad Montrie, Making a Living: Work and Environment in the United States (Chapel Hill: University of North Carolina Press, 2008), 113-28; Donald Worster, Rivers of Empire: Water, Aridity and the Growth of the American West (Oxford and New York: Oxford University Press, 1985).

14 On the environmental history of the Amazon region, see José Augusto Pádua, "Biosfera, História e Conjuntura na Análise da Questão Amazónica," História, 
Ciências, Saúde—Manguinhos 6 (September 2000): 793-811, and Pádua, “'Drawn by Blind Greed'": The Historical Origins of Criticism Regarding the Destruction of the Amazon River's Natural Resources," in A History of Water, Series II, Vol. 3, ed. Terje Tvedt, Graham Chapman, and Roar Hagen (London: I.B. Tauris, 2011).

15 Silvino Santos, No País das Amazonas (1921), Museu da Imagem e do Som do Amazonas (MISAM), Manaus, BR. Many thanks to MISAM for sending a DVD copy to the University of Coimbra in March 2012.

16 Carolyn Merchant, Reinventing Eden: The Fate of Nature in Western Culture (New York: Routledge, 2004), 11-64.

17 Felipe Milanez, "Faroeste caboclo," Rolling Stone Brazil (December 2007): 76-83; see also the report of the Pastoral Land Commission on the violence against rural workers in today's Brazilian Amazon: Commissão Pastoral da Terra, Diagnóstico sobre as situações de ameaça de morte contra trabalhadores e trabalhadoras rurais do Sul e Suleste do Pará (2012); many thanks to Felipe Milanez for pointing me to this source.

18 This is what emerged from a report filed by the British diplomat Roger Casement in 1910-11. See Jordan Goodman, The Devil and Mr. Casement: One Man's Battle for Human Rights in South America's Hearth of Darkness (New York: Farrar, Straus and Giroux, 2010). See also Roger Casement, The Amazon Journal of Roger Casement, ed. Angus Mitchell (London: Anaconda Editions, 1997). I am thankful to Xenia Wilkinson for pointing me to Casement's report.

19 On Santos, see Flávio Araújo Lima Bittencourt, "Silvino Santos," Biblioteca Virtual das Amazonasa, Série Memória. http://www.bv.am.gov.br/portal/conteudo/serie_ memoria/04_silvino.php (last accessed October 16, 2012).

20 Williams, "Ideas of Nature," 78.

21 See, for example, Donald Worster, Dust Bowl: The Southern Plains in the 1930s (Oxford and New York: Oxford University Press, 1979). On a global scale, see also Paul Josephson, Industrialized Nature: Brute Force Technology and the Transformation of the Natural World (Washington, DC: Island Press, 2002).

22 Thomas Andrews, Killing for Coal: America's Deadliest Labor War (Cambridge and London: Harvard University Press, 2008).

23 Myrna Santiago, The Ecology of Oil: Environment, Labor, and the Mexican Revolution, 1900-1938 (Cambridge and New York: Cambridge University Press, 2006).

24 Myrna Santiago, "Work, Home and Natural Environments: Health and Safety in the Mexican Oil Industry, 1900-1938," in Dangerous Trades: Histories of Industrial Hazards across a Globalizing World, ed. Christopher Sellers and Joseph Melling (Philadelphia: Temple University Press, 2012), 41.

25 Arthur McEvoy, "Working Environments: An Ecological Approach to Industrial Health and Safety," Technology and Culture 36 (April 1995): S145-73.

26 Christopher Sellers, Hazards of the Job: From Industrial Hygiene to Environmental Health Science (Chapel Hill and London: University of North Carolina Press, 1998).

27 See, for example, Peter Bartrip, The Way from Dusty Death. Turner and Newall and the Regulation of Occupational Health in the British Asbestos Industry, 1890-1970 (London and New York: Athlone Press, 2001); Francesco Carnevale and Davide Baldasseroni, Mal da lavoro. Storia della salute dei lavoratori (Rome-Bari: Laterza, 1999); Ray Elling, The Struggle for Workers' Health: A Study of Six Industrialized Countries (New York: Baywood, 1986); Roy Johnston Roy and Arthur McIvor, Lethal 
Work. A History of the Asbestos Tragedy in Scotland (Tuckwell: The Mill House, 2000); Gerald Markowitz and David Rosner, Deceit and Denial. The Deadly Politics of Industrial Pollution (Berkeley: University of California Press, 2002); David Rosner and Gerald Markowitz, Dying for Work: Workers' Safety and Health in Twentieth-Century America (Bloomington: Indiana University Press, 1986).

28 See, for example, Sellers and Melling, Dangerous Trades.

29 Stefania Barca, "Lavoro, corpo, ambiente. Laura Conti e le origini dell'ecologia politica in Italia," Ricerche Storiche 41 (September-December 2011): 541-50.

30 Laura Conti, Che cos'él'ecologia. Capitale, lavoro, ambiente (Milan: Mazzotta, 1977): 135-36.

31 Saverio Luzzi, Il Virus del Benessere. Ambiente, Salute e Sviluppo nell'Italia Repubblicana (Rome-Bari: Laterza, 2009), 100-1; Wilko Graf von Hardenberg and Paolo Pelizzari, "The Environmental Question, Employment and Development in Italy's Left," Left History 2 (2008): 77-104.

32 Roberto Della Seta, La Difesa dell'Ambiente in Italia (Milan: Franco Angeli, 2000), 46.

33 Saverio Luzzi, "Il Virus del Benessere," in Industria, ambiente e territorio. Per una storia ambientale delle aree industriali in Italia, ed. Salvatore Adorno and Simone Neri Serneri (Bologna: Il Mulino, 2009).

34 On the Seveso accident and on the subsequent European Union directives, see http://ec.europa.eu/environment/seveso/index.htm (last accessed October 20, 2012).

35 Laura Conti, Visto da Seveso. L'Evento Straordinario e l'Ordinaria Amministrazione (Milan: Feltrinelli, 1977), 56.

36 Laura Centemeri, Ritorno a Seveso. Il Danno Ambientale, il suo Riconoscimento, la sua Riparazione (Milan: Mondadori, 2006).

37 Virginio Bettini and Barry Commoner, Ecologia e lotte sociali. Ambiente, popolazione, inquinamento (Milan: Feltrinelli, 1976), 6.

38 On the abortion debate in Italy as related to the Seveso accident, see Bruno Ziglioli, La Mina Vagante. Il Disastro di Seveso e la Solidarietà Nazionale (Milan: Franco Angeli, 2010).

39 Conti, Visto da Seveso, 54.

40 Chad Montrie, To Save the Land and People: A History of Opposition to Coal Strip Mining in Appalachia (Chapel Hill: University of North Carolina Press, 2002). On the impact of strip-mining on local communities, see also the more recent Michele Morrone and Geoffrey L. Buckley, eds., Mountains of Injustice: Social and Environmental Justice in Appalachia (Athens: Ohio University Press, 2011), and Shirley Stewart Burns, Bringing Down the Mountains: The Impact of Mountaintop Removal Surface Coal Mining on Southern West Virginia Communities, 1970-2004 (Morgantown: West Virginia University Press, 2007).

41 Gregory Rosenthal, "Life and Labor in a Seabird Colony: Hawaiian Guano Workers, 1857-70," Environmental History 17 (October 2012): 744-82.

42 Stacy Alaimo, Bodily Natures. Science, Environment and the Material Self (Bloomington and Indianapolis: Indiana University Press, 2010).

43 Andrew Hurley, Environmental Inequalities: Race, Class and Environmental Pollution in Gary, Indiana (Chapel Hill: University of North Carolina Press, 1995). For a 
review of US literature on class in environmental history, see Chad Montrie, $A$ People's History of Environmentalism in the United States (London: Continuum, 2011), 147-57.

44 Hurley, Environmental Inequalities; Robert Gottlieb, Forcing the Spring: The Transformation of the American Environmental Movement (Washington, DC: Island Press 1993); Daniel Faber, ed., The Struggle for Ecological Democracy: Environmental Justice Movements in the United States (New York: Guilford Press, 1998). For a synthesis on historical relationships between occupational and environmental hazards in the United States, see John Froines, Robert Gottlieb, Maureen Smith, and Pamela Yates, "Disassociating Toxic Policies: Occupational Risk and Product Hazard," in Reducing Toxics: A New Approach to Policy and Industrial Decisionmaking, ed. Robert Gottlieb (Washington, DC, and Covelo: Island Press, 1995).

45 Richard W. Judd, Common Lands, Common People: The Origins of Conservation in Northern New England (Cambridge: Harvard University Press, 1997), vii.

46 Gunther Peck, "The Nature of Labor: Fault Lines and Common Ground in Environmental and Labor History," Environmental History 11 (2006): 212-38.

47 Lawrence M. Lipin, Workers and the Wild: Conservation, Consumerism, and Labor in Oregon, 1910-30 (Urbana and Chicago: University of Illinois Press, 2007); Chad Montrie, Making a Living: Work and Environment in the United States (Chapel Hill: University of North Carolina Press, 2008).

48 Scott Dewey, "Working for the Environment: Organized Labor and the Origins of Environmentalism in the United States, 1948-1970," Environmental History 1 (1998): 45-63.

49 Gottlieb, Forcing the Spring, and Montrie, Making a Living, 91-128.

50 Robert Gordon. "Shell No!' OCAW and the Labor-Environmental Alliance," Environmental History 4 (1998): 460-87.

51 Gottlieb, Forcing the Spring, 365-66.

52 Brian Obach, Labor and the Environmental Movement: The Quest for Common Ground (Cambridge: MIT Press, 2004).

53 See, for example, Patrick Novotny, Where We Live, Work and Play: The Environmental Justice Movement and the Struggle for a New Environmentalism (Westport and London: Praeger, 2000), 41-72; see also William Brucher, "From the Picket Line to the Playground: Labor, Environmental Activism, and the International Paper Strike in Jay, Maine," Labor History 52 (Winter 2011): 95-116. For a Brazilian perspective on environmental justice and work, see Henri Acselrad, Selene Herculano, and José Augusto Pádua, eds., Justiça Ambiental e Cidadania (Rio de Janeiro: Relume Dumará, 2004), and Marcelo Firpo Porto, "Saúde do trabalhador e o desafio ambiental: contribuições do enfoque ecossocial, da ecologia política e do movimento pela justiça ambiental," Ciênça e Saúde Coletiva 10 (2005): 829-39.

54 Robert D. Bullard, Dumping in Dixie: Race, Class and Environmental Quality (Boulder: Westview Press, 2000), 86.

55 Laura Pulido, Environmentalism and Economic Justice: Two Chicano Struggles in the South (University of Arizona Press, 1996), 3-56.

56 On the "environmental conflict" concept, see Robert Bullard, Dumping in Dixie, 9 11, and Joan Martinez Alier, The Environmentalism of the Poor: A Study in Environmental Conflicts and Valuation (Cheltenham: Edward Elgar, 2002); for an environmental history approach, see Marco Armiero, "Seeing Like a Protester: Nature, 
Power and Environmental Struggles," Left History 13 (Spring-Summer 2008): $59-76$.

57 David Pellow, Garbage Wars: The Struggle for Environmental Justice in Chicago (Cambridge and London: MIT Press, 2002), 12.

58 David Pellow, Garbage Wars, 131-60.

59 Mary Allegretti, "A construção social de políticas públicas. Chico Mendes e o movimento dos seringueiros," Desenvolvimento e Meio Ambiente 18 (July-December 2008): 39-59; see also M. Keck, "Social Equity and Environmental Politics in Brazil: Lessons from the Rubber Tappers of Acre," Comparative Politics 27 (July 1995): 409-24; Gomercindo Rodriguez, ed., Walking the Forest with Chico Mendes: Struggle for Justice in the Amazon (Austin: University of Texas Press, 2007).

60 Biorn Maybury-Lewis, "Introduction to the English Edition," in Walking the Forest, $10-11$.

61 Gianfranco Bettin, ed., Petrolkimiko: le Voci e le Storie di un Crimine di Pace (Milan: Baldini Castoldi Dalai, 1998); Barbara Allen, "A Tale of Two Lawsuits: Making Policy/Relevant Environmental Health Knowledge in Italian and U.S. Chemical Regions," and Stefania Barca, "Bread and Poison. The Story of Labor Environmentalism in Italy," in Dangerous Trades, 154-67 and 126-39; Giulio Di Luzio, Fantasmi dell'Enichem (Milan: Baldini Castoldi Dalai, 2003); David Allen and Laurie Kazan-Allen, Eternit and the Great Asbestos Trial (London: IBAS 2012).

62 On "just transition," see, for example, United Nations Environment Programme, Report of the Trade Union Assembly on Labour and the Environment on the Work of Its First Meeting, Nairobi, January 15-17, 2006 (UNEP/DPDL/TUALE/1). See also http://en.wikipedia.org/wiki/Just_Transition and http://www.hazards.org/greenjobs/ (last accessed October 20, 2012). 